ZalącZnils

Uznanie autorstwa-Użycie niekomercyjne-Bez utworów zależnych

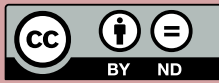

Załącznik Kulturoznawczy 4/2017

DOCIEKANIA KULTUROLOGICZNE

\title{
DO CZEGO KONIECZNY JEST JĘZYK? \\ CO JEST KONIECZNE W JĘZYKU?
}

MAGDALENA DANIELEWICZOWA

Wydział Neofilologii, Uniwersytet Warszawski

Faculty of Modern Languages, University of Warsaw

m.m.danielewicz@uw.edu.pl

W artykule tym chciałabym zarysować odpowiedzi na dwa tytułowe pytania, które pozostają ze sobą w bezpośrednim i ścisłym związku. Zacznę od zajęcia stanowiska w sprawie relacji między językiem naturalnym a kodami zwierzęcymi z jednej strony i innymi zjawiskami zaliczanymi do sfery kultury - z drugiej, by następnie przejść do wskazania i krótkiego omówienia tych własności języka, które decydują o jego istocie, są konstytutywne i niezbywalne, które właśnie sprawiają, że, po pierwsze, różne zestawy sygnałów, jakie wysyłają do siebie w obrębie określonych gatunków zwierzęta, oddziela od ludzkiej mowy nie zaledwie płynna granica, ale prawdziwa przepaść, po drugie natomiast - język jest wśród innych systemów znakowych instytucją szczególną i wyróżnioną.

\section{WŁADZA JĘZYKOWA JAKO ZJAWISKO SWOIŚCIE LUDZKIE}

Już na samym wstępie odrzucam dominujące we współczesnej antropologii, neurobiologii czy prymatologii stanowisko, jakoby języki, jakimi posługują się obecnie różne społeczności ludzkie, były produktem ewolucyjnego przekształcenia i rozwoju bądź to rozmaitych pohukiwań (w teoriach wokalnych), bądź to ekspresywnych gestów (w teoriach gesturalnych) wyżej zorganizowanych małp, w szczególności szympansów i orangutanów, których kod genetyczny, jak twierdzą specjaliści, w ponad dziewięćdziesięciu procentach jest zgodny z kodem ludzkim ${ }^{1}$. Tym samych kwestionuję również istnienie

${ }^{1}$ Na temat różnych ewolucyjnych teorii dotyczących glottogenezy zob. na przykład: R. Leakey, Pochodzenie człowieka, tłum. Z. Skrok, Warszawa 1995, s. 63-189; 
w dziejach istot mówiących protojęzyka, którego miałyby używać od 4 do 1,5 miliona lat temu austrolopiteki lub znacznie później (ewolucjoniści nie są co do tych datowań zgodni), bo dopiero w okresie paleolitu - to znaczy około 35 tysięcy lat temu - hominidzi, a który miałby być ogniwem łączącym zwierzęce sygnały i język ludzki. Rozmaite opisy takiego protojęzyka, głoszące na przykład, że pierwotnie składał się on wyłącznie z nazw indywiduów i zdarzeń, ale nie zawierał określeń relacji ${ }^{2}$, albo też ustanawiające kolejność pojawiania się w różnych okresach poszczególnych pojęć, także semantycznie prostych i uniwersalnych ${ }^{3}$, są nienaukowe w tym sensie, że niemożliwe do sfalsyfikowania. Również swoboda w przesuwaniu, bez jakichkolwiek argumentów lingwistycznych, prapoczątków mowy o milion lat do tyłu lub o parędziesiąt tysięcy lat do przodu musi budzić poważne wątpliwości. Nie ma, niestety, bezpośredniego przejścia od obserwacji dotyczących pozostałości materialnych w postaci czaszek, szkieletów, prymitywnych narzędzi i tym podobnych artefaktów, do wniosków na temat zjawiska całkowicie pozbawionego cech fizykalnych, jakim jest język.

Poważny wgląd w strukturę ludzkiej mowy pozwolił językoznawcom XX i XXI wieku opisać jej konieczne, definicyjne własności, a tym samym odkryć rządzące nią mechanizmy. Albo pewien kod jest w ten mechanizm wyposażony, a wtedy automatycznie uznamy go za język taki, jak nasz, albo jest tej maszynerii pozbawiony i żadne ulepszenia w postaci dodawania doń

S. Pinker, Język jest instynktem ludzkim, przeł. J. i M. Jannaszowie, [w:] Trzecia kultura, red. J. Brockman, Warszawa 1996; J. Aitchison, Ziarna mowy. Początki i rozwój języka, tłum. M. Sykurska-Derwojed, Warszawa 2002; P. Żywiczyński, S. Wacewicz, Ewolucja języka. W stronę hipotez gesturalnych, Lublin 2015.

2 Taka teza została zgłoszona w pracy W. Calvina i D. Bickertona, Lingua ex Machina. Reconciling Darwin and Chomsky with the Human Brain, Cambridge 2001.

C. Goddard, A. Wierzbicka, H. Fabréga Jr. w artykule Evolutionary semantics: using NSM to model stages in human cognitive evolution, „Language Sciences” 2013, No. 42, s. 60-79, wyróżniają sześć takich etapów kształtowania się NSM, czyli naturalnego metajęzyka semantycznego. Pierwsze pojęcia, a mianowicie 'ręce', 'nogi', 'głowa', 'twarz', miały rzekomo pojawić się na drugim etapie rozwoju hominidów, około 4-3 milionów lat temu, w związku przyjęciem przez nich postawy wyprostowanej. 
nowych elementów czy nawet całych ich zestawów niczego tu nie zmienią. Przywołajmy w tym miejscu znamienny cytat z Wilhelma Humboldta, który w Über das vergleichende Sprachstudium, 13 uznał mowę za zjawisko bezpośrednio tkwiące w człowieku:

[...] nic nie pomoże, jeśli na jej wynalezienie poświęcimy tysiąclecia i jeszcze tysiąclecia. [...] Aby człowiek naprawdę rozumiał choćby jedno jedyne słowo, nie jako zwykły impuls zmysłowy, lecz jako artykułowany, oznaczający pojęcie dźwięk, musi już mowa tkwić w nim całkowicie: w całym swym uwikłaniu .

Racjonalne stanowisko w sprawie genezy mowy zajmował Ferdynand de Saussure ${ }^{5}$, uważany za ojca współczesnej lingwistyki. Wyznawał on mianowicie paradoksalną zasadę jednoczesnej zmienności i niezmienności języka w czasie oraz zmienności i niezmienności języka w przestrzeni. Uważał, że ten, kto chce się czegoś dowiedzieć o źródłach danego idiomu, powinien badać jego stan współczesny; podkreślał tym samym, że język naszych najodleglejszych nawet przodków nie różnił się niczym zasadniczym od języka, którym różne społeczności ludzkie posługują się obecnie, a to dlatego, że zarówno w czasie, jak i w przestrzeni, o ile nie dojdzie w nim do jakiegoś gwałtownego zaburzenia, zachowuje on ciągłość, choć jednocześnie podlega stałym przekształceniom. Projektowane przez genewskiego uczonego językoznawstwo ogólne miało potwierdzić, iż istota zjawisk językowych:

jest - po pierwsze - wszędzie taka sama, a po drugie, że zawsze była taka sama, tak mianowicie, że błędem jest sądzić, iżby problem pochodzenia języka miał być czymś innym niż ten, który dotyczy jego przekształceń. Byłby to inny problem, gdybyśmy założyli, że w mowie ludzkiej działały kiedyś odmienne siły, których nie możemy sobie wyobrazić na podstawie tego, co się dzieje, kiedy mówimy, również dzisiaj; ale takie założenie jest w tym samym stopniu arbitralne, co nieprawdziwe - zmierza ono do przypisania

${ }^{4}$ Cyt. za: M. Scheler, Pisma $z$ antropologii filozoficznej i teorii wiedzy, tłum. i oprac. S. Czerniak, A. Węgrzecki, Warszawa 1987, s. 3-42 (kursywa oryginalna).

5 F. de Saussure, Szkice zjęzykoznawstwa ogólnego, tłum. M. Danielewiczowa, Warszawa 2004, s. 142-167. 
ludom pierwotnym władz i zmysłów zasadniczo różnych od tych, które my mamy $[\ldots]^{6}$.

Uderzająco podobne do tez de Saussure’a są myśli Johna Lyonsa, brytyjskiego językoznawcy, młodszego od genewczyka o blisko osiemdziesiąt lat, który w punkcie 1.7 (pod znaczącym tytułem Nie ma żadnych prymitywnych języków) swej znanej pracy Language and Linguistics. An Introduction pisze:

Nadal dosyć często słyszy się laików mówiących o prymitywnych językach, a nawet powielających zdyskredytowany mit, jakoby istniały jakieś ludy, których język składa się z paruset wyrazów uzupełnionych gestami. Prawda jest taka, że każdy z dotychczas badanych języków - niezależnie od tego, jak prymitywne bądź niecywilizowane pod innymi względami mogłoby się nam wydawać społeczeństwo, które go używa - po dogłębnej analizie okazał się złożonym i wysoce rozwiniętym systemem komunikacyjnym. Cała hipoteza ewolucji kulturowej od barbarzyństwa do cywilizacji jest sama w sobie mocno wątpliwa. Ale nie do lingwisty należy wypowiadanie opinii na temat jej prawdziwości. Jest on natomiast w stanie stwierdzić, że nie odkryto dotychczas żadnego związku między poszczególnymi etapami rozwoju kulturowego, przez które przeszły społeczeństwa, a typami języka używanego w tych stadiach kulturowego rozwoju. Nie istnieje, na przykład, nic takiego jak typ języka epoki kamienia lub też, biorąc pod uwagę ogólną strukturę gramatyczną, typ języka, który charakteryzowałby społeczeństwa trudniące się zbieractwem czy pasterstwem $\mathrm{z}$ jednej strony i współczesne uprzemysłowione społeczeństwa $\mathrm{z}$ drugiej strony. [...] W ciągu dziewiętnastego wieku lingwiści zaczęli zdawać sobie sprawę z tego, że jakkolwiek daleko wstecz usiłowano prześledzić historię danych języków w tekstach, które dotrwały do naszych czasów, niemożliwe było dostrzeżenie w nich jakichkolwiek śladów ewolucyjnego rozwoju od bardziej prymitywnego do bardziej zaawansowanego stanu?

Na zakończenie tego fragmentu mojego opracowania przywołam jeszcze stanowisko Andrzeja Bogusławskiego i Ewy Drzazgowskiej - autorów

6 Ibidem, s. 155.

7 J. Lyons, Language and Linguistics. An Introduction, Cambridge 1981, s. 27-29. Powyższy cytat podaję w poprawionym przez siebie pod względem redakcyjnym tłumaczeniu, które można znaleźć na stronie internetowej: http://potop-exodus.w.interiowo.pl/babel/lingwisci.html [dostęp: 17.10.16]. 
dwutomowego dzieła poświęconego historii myśli lingwistycznej, którzy fizjologiczne rozważania na temat pochodzenia języka, mieszczące się w nurcie post- lub neodarwinistycznym, określają mianem domysłów mających „charakter niepoważnych anegdot lub źle ukierunkowanych spekulacji” i przyjmują w swej pracy strategię wypracowaną przez Société de Linguistique de Paris. Towarzystwo to w 1866 roku zakazało jakiejkolwiek debaty na temat początków języka, uznawszy te kwestie za niepoważny problem, który przyciąga głównie szaleńców i fantastów.

\section{JEZYYK - WARUNEK KONIECZNY KULTURY}

$\mathrm{W}$ różnych podręcznikach, a od czasu do czasu również w autorskich monografiach mających poważniejszy charakter naukowy, można niekiedy przeczytać, że język jest co prawda swoistym, ale też jednym $\mathrm{z}$ wielu elementów kultury, obok instytucji czy osiągnięć, takich na przykład jak taniec, malarstwo, rzemiosło czy moda. Taki obraz wyłania się w szczególności z rozważań poświęconych rozmaitym typologiom znaków, dla których niemal powszechną praktyką jest traktowanie wyrażeń językowych jako pewnego podtypu dzielonej kategorii, znajdującej się na tym samym poziomie, co oznaki czy indeksy (takie jak trop zwierzęcia na śniegu), ikony (w rodzaju czyjejś karykatury), czy też symbole (jakimi są na przykład biała bądź czerwona flaga wywieszone na plaży) $)^{9}$ W pewnym stopniu za przedstawiony wyżej stan rzeczy odpowiada propagatorska siła ujęcia utrwalonego w Kursie językoznawstwa ogólnego ${ }^{10}$, w którym to dziele semiologia, czyli projektowana nauka o znakach, miała być częścią psychologii ogólnej i zajmować

8 A. Bogusławski, E. Drzazgowska, Język $w$ refleksji teoretycznej. Przekroje historyczne, t. I-II, Warszawa 2016, s. 28.

9 Por. na przykład: B. Bojar, Zarys językoznawstwa dla studentów bibliotekoznawstwa i informacji naukowej, Warszawa 1991, s. 31; I. Bobrowski, Zaproszenie do językoznawstwa, Kraków 1998, s. 43-44; E. Łuczyński, J. Maćkowiak, Językoznawstwo ogólne. Wybrane zagadnienia, Gdańsk 1999, s. 10-12; R. Przybylska, Wstęp do nauki o języku polskim. Podręcznik dla szkół wyższych, Kraków 2003, s. 12-18; R. Grzegorczykowa, Wstęp do językoznawstwa, Warszawa 2007, s. 15-21.

10 F. de Saussure, Kurs językoznawstwa ogólnego, tłum. K. Kasprzyk, Warszawa 2002. 
się, obok języka naturalnego, również innymi systemami znaków ${ }^{11}$. Choć w przywołanym dziele zaznaczone zostało, że nowej dyscyplinie powinna patronować lingwistka, ponieważ języki, jakimi posługują się ludzie, są kodami najpowszechniejszymi i najbardziej złożonymi ${ }^{12}$, w świadomości znacznej części odbiorców Kursu... pozostało przede wszystkim dowartościowanie, na równi z ludzką mową, innych systemów semiotycznych.

Oryginalne pisma F. de Saussure’a nie zostawiają wątpliwości co do tego, że uczony uważał język naturalny za instytucję wśród innych wyróżnioną, o takim mianowicie charakterze, że wszystkie ,inne ludzkie ustanowienia, z wyjątkiem pisma, mogą nas jedynie co do jej prawdziwej istoty mylić, o ile na nasze nieszczęście zaufamy ich analogii”. Dodawał przy tym, że ktokolwiek postawi nogę na gruncie języka, zostanie pozbawiony jakichkolwiek zestawień i porównań „ze zjawiskami niebieskimi i ziemskimi”. Język bowiem to jedyny system semiologiczny, który „musi się zmierzyć z doświadczeniem czasu"13, choćby dlatego, że stanowi przedmiot międzypokoleniowej transmisji.

Claude Lévi-Strauss, badacz - jak wiadomo - zainspirowany myślą de Saussure'a, w wywiadzie z Georges'em Charbonnierem podkreślał, że linię demarkacyjną między naturą a kulturą wyznacza nie tyle obecność narzędzi, na co często zwracają uwagę antropolodzy, ile mowa artykułowana. Język bowiem jest:

[...] najdoskonalszym ze wszystkich przejawów porządku kulturowego i jeśli chcemy zrozumieć, czym jest sztuka, religia, prawo, a może nawet i kuchnia lub zasady uprzejmości, należy je rozumieć jako kody utworzone przez artykulację znaków, według modelu lingwistycznego porozumiewania się ${ }^{14}$.

W podobny sposób na temat stosunku między językiem a innymi kodami kultury wypowiadał się Roman Jakobson, który badaczom różnych systemów porozumiewania się zalecał, by nie zapominali, że:

${ }^{11}$ Ibidem, s. 44.

12 Ibidem, s. 92.

13 F. de Saussure, Szkice..., op. cit., s. 199, 206 i 242.

14 G. Charbonnier, Rozmowy z Claude Lévi-Straussem, tłum. J. Trznadel, Warszawa 2000, s. 141. 
[...] dla całej ludzkości język jest głównym środkiem komunikacji oraz że tę hierarchię chwytów komunikacji z konieczności odbijają wszystkie inne, wtórne typy komunikatów ludzkich. W różny sposób są one zależne od języka, mianowicie od jego wcześniejszego przyswojenia oraz od jawnych i ukrytych językowych wypowiedzi, które towarzyszą wszelkim innym komunikatom lub je interpretują ${ }^{15}$.

Jeszcze bardziej dobitnie, bo w sposób czysto formalny, kwestię relacji między językiem naturalnym a innymi systemami semiotycznymi stawia Andrzej Bogusławski. Autor ten w paru swoich opracowaniach ${ }^{16}$ zaprezentował wywód wykluczający istnienie części wspólnych między tym, co idiomatycznie ludzie nazywają znakami, a wyrażeniami językowymi, które w mowie zwykłych użytkowników znakami nazywane nigdy nie są. Sformułował również tezę, że między znakami (takimi na przykład, jak gwizdek oznaczający odjazd pociągu) a wyrażeniami językowymi zachodzi implikacja jednostronna, w tym sensie, że znak, w potocznym sensie tego słowa, jest ustanawiany na mocy użycia języka, nie odwrotnie. Co więcej, funkcję znaków mogą pełnić również elementy izolowane, takie jak na przykład czarna chorągiew zawieszona na bramie uniwersyteckiej, sygnalizująca pogrzeb jednego z profesorów, podczas gdy wyrażenia językowe swe istnienie zawdzięczają jedynie opozycjom, w jakie wchodzą z innymi jednostkami. W takiej perspektywie uogólnienie, które obejmowałoby wyrażenia językowe i znaki jako klasy stojące obok siebie, jak również redukowanie tych pierwszych do drugich, prowadzi nieuchronnie do regresu nieskończonego. $\mathrm{Z}$ formalnego rozumowania Bogusławskiego jednoznacznie wynika, że warunkiem koniecznym ustanowienia przez człowieka jakiegokolwiek zjawiska czy kodu kulturowego, a także zinterpretowania dowolnego faktu czy stanu rzeczy w kategoriach znaku, czyli uruchomienia dowolnego procesu semiozy, jest wyposażenie w język.

15 R. Jakobson, Język a inne systemy komunikacji, tłum. A. Tanalska, [w:] idem, W poszukiwaniu istoty języka. Wybór pism, t. I, red. M.R. Mayenowa, Warszawa 1989, s. 61.

${ }_{16}$ Zob. na przykład: A. Bogusławski, Język $i$ świat znaków, „Przegląd Humanistyczny" 1988, nr 12, s. 133-168; idem, Słowo i znak, [w:] Znaki czy nie znaki?, red. M. Guławska-Gawkowska, G.M. Zeldowicz, Warszawa, 2013, s. 9-19; A. Bogusławski, E. Drzazgowska, op. cit., t. I, s. 18-20. 
Po tych rozważaniach, mających na celu przypomnienie rzeczywistej, bo podyktowanej względami logicznymi zależności między zdolnością mowy a wszystkimi innymi władzami i osiągnięciami człowieka, przechodzę do omówienia podstawowych własności, które są w języku niezbywalne, a tym samym pozwalają odróżnić tę instytucję nie tylko od kodów zwierzęcych, lecz także od w tórnych w stosunku do niej i na niej ufundowanych systemów semiotycznych, za pomocą których ludzie organizują swą kulturową przestrzeń. Trzeba przy tym odróżnić tak zwane uniwersalia językowe, to znaczy cechy, które występują we wszystkich bez wyjątku ludzkich idiomach ${ }^{17}$, od tych lingwistycznych własności, które są zdeterminowane logicznie. Tylko te drugie będą dalej przedmiotem mojego zainteresowania. Przywołane zbiory nie mają identycznych zakresów. Dla przykładu, wszystkie języki posługują się jako nośnikiem znaczenia dźwiękiem, który nie tylko nie stanowi w procesie komunikacji elementu koniecznego, lecz, co więcej, przy pewnym rozumieniu tego problemu, jest całkowicie obcy naturze języka ${ }^{18}$. Chodzi mianowicie o to, że w języku (langue) - rozumianym jako z natury bezcielesny, będący dobrem wspólnym i systemem opozycji - nie ma miejsca na jednostkowe zjawiska fizykalne. Te mogą być obserwowane jedynie w indywidualnym akcie mowy (parole), będącym przejawem woli mówiącego. Dźwięk jest, co prawda, najwygodniejszym środkiem przekazywania sensów, ale nie należy zapominać, że na przykład osoby niesłyszące z powodzeniem posługują się inną, a mianowicie manualno-przestrzenną formą wyrazu.

\section{PODWÓJNE ROZCZŁONKOWANIE JĘZYKA}

Niezbywalną cechą języka naturalnego jest jego podwójne rozczłonkowanie lub - jak czasami się to określa - podwójna artykulacja (od lac. articulus 'cząstka'). Własność ta, powiązana logicznie z kwestią linearności wyrażeń językowych, sprowadza się do tego, że z potoku mowy można wydobywać jednostki dwojakiego rodzaju: po pierwsze takie, które są bilateralne, $w$ tym sensie, że mają zarówno płaszczyznę wyrażenia, jak i płaszczyznę treści; po drugie takie, które służą do rozróżniania znaczeń, pełnią więc funkcje

${ }_{17}$ Listę takich uniwersaliów podał na przykład Charles Hockett w artykule: Zagadnienie uniwersaliów w języku, tłum. H. Kurkowska, [w:] Językoznawstwo strukturalne, red. A. Weinsberg, H. Kurkowska, Warszawa 1979, s. 209-228.

18 Por. F. de Saussure, Szkice..., op. cit., s. 41-45. 
diakrytyczne, ale same w sobie znaczenia nie mają. Problem podwójnego rozczłonkowania najdobitniej sformułowany został w ważnej wypowiedzi francuskiego strukturalisty André Martineta z 1960 roku $^{19}$.

Produkty pierwszego (przede wszystkim w sensie hierarchii ważności) podziału łączy wspólna cecha znaczącości, a różni to, że mogą one należeć do różnych podsystemów czy też reprezentować różne rangi wyrażeń. Na przykład w wypowiedzeniu: Oto nasza pływalnia wyodrębnić można segment zdaniotwórczy oto, dystrybucyjnie odpowiadający czasownikowi $\mathrm{w}$ formie finitywnej, i grupę imienną nasza pływalnia. Oba te ciągi mają charakter bilateralny. Można również rozpatrywaną całość podzielić od razu na elementy prostsze, to znaczy na formy wyrazowe: oto, nasza, pływalnia, reprezentujące poziom jednostek leksykalnych. Można w końcu, nie odchodząc wciąż od formuły pierwszego rozczłonkowania, wskazać $\mathrm{w}$ analizowanym przykładzie minimalne jednostki znaczące: oto, nasz-, $-a$, pływ-, -alń, - $a$, będące aktualizacjami odpowiednich morfemów ${ }^{20}$ rdzennych (/oto/, /nasz/, /pływ/), słowotwórczych (/alń/) i gramatycznych (/a/). $\mathrm{W}$ drugim rozczłonkowaniu sekwencję rozwijającą się na linii czasu (w wypowiedzi ustnej) lub w przestrzeni (w tekście pisanym) dzielimy na jednostki unilateralne, to znaczy głoski: $o, t, o, n, a, \check{s}, a, p, \ell, y, w, a, l, \grave{n}, a$, stanowiące realizacje określonych fonemów (w tekście pisanym reprezentowane są one przez odpowiednie litery lub połączenia liter).

Podwójna artykulacja wypowiedzi, a co za tym idzie: również języka, zapewnia systemowi kombinatoryczność i, w konsekwencji, ekonomiczność, a jego użytkownikowi pozwala minimalizować wysiłek związany z zapamiętywaniem ogromu znaczeń i opozycji, w jakie znaczenia te wchodzą. Ze stosunkowo niewielkiej liczby cząstek znaczących skonstruowane są w języku naturalnym miliony jednostek leksykalnych; zaledwie parę dziesiątków fonemów tworzy z kolei płaszczyznę wyrażenia wszystkich jego elementów

19 Chodzi o I rozdział książki A. Martineta: Éléments de linguistique générale, Paris 1960, s. 17-22. Zob. polskie wydanie pod tytułem: Podstawy lingwistyki funkcjonalnej, wybór i tłum. L. Zawadowski Warszawa 1970, s. 18-24; lub przedruk: [Podwójne rozczłonkowanie języka], [w:] Semiotyka dziś i wczoraj, red. L. Koj, J. Pelc, Wrocław 1991, s. 342-345.

20 Martinet we wspomnianym wyżej opracowaniu posługuje się w tym miejscu terminem 'monem'. 
dwustronnych. Jakobson w przywoływanym już wcześniej artykule podkreśla, że „bogaty repertuar elementów znaczących (słów i morfemów) jest możliwy dzięki istnieniu ich składników wyłącznie różnicujących (fonemów, cech dystynktywnych), a więc produktów drugiego rozczłonkowania"21.

Taka podwójna struktura, konieczny rys ludzkiej mowy, nie występuje w żadnym innym systemie semiotycznym.

\section{DWUKLASOWOŚĆ JĘZYKA}

Ustanowienie, które pretenduje do miana języka naturalnego, musi ponadto obejmować dwie klasy jednostek, to znaczy, z jednej strony, wyrażenia składające się na jego słownik, $\mathrm{z}$ drugiej zaś - jednostki operacyjne ${ }^{22}$ tworzące jego gramatykę. Takie wyposażenie zapewnia kodowi generatywnośći kreatywność. Dzięki tej cesze mówiącym dana jest możliwość przechodzenia od langue - systemu elementów zmagazynowanych w zbiorowej pamięci danej wspólnoty etnicznej, z której każdy jej uczestnik czerpie - do parole, to znaczy indywidualnych wypowiedzi stanowiących linearne układy elementów wybranych ze słownika i ukształtowanych gramatycznie na mocy jednostkowej decyzji nadawcy. Odwołując się do terminologii de Saussure'owskiej, można by tu również mówić o przechodzeniu od porządków asocjacyjnych (czy paradygmatycznych) do związków o charakterze syntagmatycznym. Jakobson z kolei ująłby to w kategoriach poruszania się między osią wyboru a osią kombinacji.

Dwuklasowość języka sprawia, że nie jesteśmy skazani na to, by posługiwać się gotowymi zdaniami, których klasa musiałaby być zamknięta, choć odpowiednio duża. W praktyce trudno nawet taką sytuację sobie wyobrazić. Omawiana cecha daje użytkownikom języka możliwość posługiwania się ogromną co prawda, ale skończoną liczbą elementów, do tworzenia nieskończonej liczby wypowiedzi, z których każda jest aktem niepowtarzalnym i twórczym, niezależnie od tego, czy chodzi o strofę autorskiego poematu, czy też, dajmy na to, o najzwyklejszą odpowiedź na pytanie.

${ }^{21}$ R. Jakobson, op. cit., s. 73.

${ }^{22} \mathrm{Na}$ temat operacyjnych jednostek języka zob. więcej w: A. Bogusławski, Towards an Operational Grammar, „Studia Semiotyczne” 1978, nr 8, s. 29-90, pol. przekład: Preliminaria gramatyki operacyjnej, tłum. R. Gozdawa-Gołębiowski, „Polonica” 1989, nr 13, s. 163-223. 


\section{PROPORCJONALNOŚĆ}

Odpowiednich jednostek leksykalnych i operacyjnych musi być w języku naturalnym tyle, by gwarantowało to jego proporcjonalność. Mechanizm ludzkiej mowy sprowadza się bowiem do układów proporcjonalnych. Cechę tę na gruncie filozofii i lingwistyki akcentowało od czasów starożytnych wielu autorów ${ }^{23}$. Szczególne miejsce w tym gronie zajmuje de Saussure, który twierdził, że język to nic innego, jak tylko stosunki stosunków, że są w nim wyłącznie opozycje, a więc różnice i tożsamości, że jest on formą, a nie substancją, że ma charakter algebraiczny. Wyrażał przekonanie, że pewnego dnia zostanie rozpoznane, iż wielkości językowe i stosunki między nimi „są w sposób regularny wyrażalne, z samej ich natury, w formułach matematycznych" ${ }^{24}$. Niezależnie od de Saussure’a i w sposób bardziej od niego precyzyjny istotę językowych tożsamości ujmował Ludwig Wittgenstein w Traktacie logiczno-filozoficznym ${ }^{25}$ i w Philosophische Grammatik ${ }^{26}$. W polskim językoznawstwie teoretycznym na tę konstytutywną cechę języka wielokrotnie $z$ wielkim naciskiem zwracał uwagę A. Bogusławski ${ }^{27}$.

Prawda o tym, że w języku wszystko zasadza się na proporcjach, daje o sobie znać w różnych odsłonach na każdym kroku: w historii dowolnego idiomu, w jego codziennym funkcjonowaniu, w rozwoju mowy najmłodszych członków danej wspólnoty. Weźmy dowolny przykład: polskie czytać do czytał ma się tak, jak biegać do biegał, jak chwytać do chwytał czy śpiewać do śpiewał. Między takimi analogicznymi formami istnieją w języku, jak mówił o tym Jerzy Kuryłowicz, distances égales - równe odległości ${ }^{28}$. Nazwy

${ }^{23}$ Obszerne omówienie sposobów traktowania analogii i proporcji w dziejach myśli lingwistycznej oraz filozoficznej znaleźć można w opracowaniu A. Bogusławskiego i E. Drzazgowskiej (op. cit., t. I, s. 356-367).

24 F. de Saussure, Szkice..., op. cit, s. 195.

25 L. Wittgenstein, Tractatus logico-philosophicus, tłum. B. Wolniewicz, Warszawa 2006, tezy: 3.141, 4.03, 4.032.

26 L. Wittgenstein, Philosophische Grammatik, hrsg. von Rush Rhees, Frankfurt am Main 1989, s. 297, 315-318.

27 Zob. przede wszystkim: A. Bogusławski, O proporcjonalności w języku i jej warunkach, [w:] Jęzkoznawstwo diachroniczne i synchroniczne, red. J. Sambor, J. Linde-Usiekniewicz, R. Huszcza, Warszawa 1993, s. 59-76.

28 J. Kuryłowicz, La nature des procčs dits «analogiques», Kraków 1949. 
tadowarka czy niszczarka utworzone zostały zgodnie z regularnym wzorcem istniejącym w polszczyźnie, a mianowicie tematowi odpowiedniego czasownika towarzyszy tu przyrostek -arka, co poświadczają liczne czwórki, szóstki, ósemki itd. proporcjonalne, a więc: spawać : spawarka, wiercić : wiertarka, zamrażać : zamrażarka, suszyć : suszarka, ładować : ładowarka, niszczyć : niszczarka. Upowszechniające się nazwy żeńskie w rodzaju filozofka czy geolożka również powoływane są do istnienia zgodnie z proporcjonalnym modelem, utrwalonym w świadomości mówiących. Wszystkie innowacje, zarówno te mieszczące się w normie, jak i pozanormatywne, mają charakter analogiczny. Polacy używają niepoprawnego bezokolicznika *wziaść, bo noszą w pamięci wyrażenia przasść, siąść czy trząść. Dzieci francuskie, jak pokazywał de Saussure, posługują się w miejsce oczekiwanego je viendrai błędną formą czasu przyszłego je *venirai, urobioną od czasownika venir, dlatego że jest to forma spełniająca narzucającą się proporcję, jedną z tych, które język wdrukowuje w ludzki umysł, a więc w tym wypadku: punir : punirai, partir : partirai, finir : finirai, mentir : mentirai itd. Znana z laciny klasycznej forma honor wyparła dawniejszy nominativus honos, bo znowu zadziałało tu prawo równania: victor $:$ victorem $=$ orator $:$ oratorem $=x$ : honorem, z czego wynika, że na miejsce $x$ powinno wejść wyrażenie honor ${ }^{29}$, nawet jeśli jest to wyrównanie analogiczne, a nie proporcja w ścisłym tego słowa znaczeniu ${ }^{30}$.

Systemowość języka, w podręcznikach akademickich definiowana często w upraszczający i naiwny sposób, nie da się dobrze uchwycić i adekwatnie przybliżyć bez koniecznego powiązania jej z zasadą proporcjonalności. Jak już była o tym wcześniej mowa, nie ma w języku naturalnym elementów izolowanych. Okoliczność ta odróżnia jego jednostki od znaków należących do innych sfer kultury. Proporcjonalność języka wyklucza też jakiekolwiek analogie $z$ sygnałami zwierzęcymi, bo w przeciwnym razie trzeba by przyjąć, że zwierzęta, podobnie jak ludzie, są zdolne do ujmowania świata w kategoriach różnic i tożsamości, a co za tym idzie - również do aktywności tak

${ }^{29}$ Jest to przykład dobrze znany z Kursu językoznawstwa ogólnego (op. cit., s. 189).

30 Słowa orator i victor mają jednak inne niż honor zakończenia, a ponadto oznaczają osoby, a nie abstrakcyjne pojęcia. 
wyszukanych, jak tworzenie neologizmów, zabawy językowe czy skomplikowane operacje logiczne.

Świadomość istnienia w danym systemie układów proporcjonalnych sprawia, że posługujący się nim ludzie postrzegają konkretne wypowiedzi nie jako pasmo niezróżnicowanych dźwięków (jak ma to na przykład miejsce w wypadku odgłosów wydawanych przez zwierzęta, niepodzielnych na segmenty funkcjonalne), ale jako ciąg, w którym następującym po sobie porcjom brzmienia odpowiadają stosowne porcje znaczeń. Wyodrębnione na mocy różnic i tożsamości wyrażenia to byty konkretne języka, tworzące jego podsystem leksykalny i morfologiczny ${ }^{31}$.

$\mathrm{Na}$ wstępie tego fragmentu mojej wypowiedzi zaznaczyłam, że w każdym języku naturalnym musi się znaleźć taka liczba elementów, jaka gwarantować będzie spełnienie zasady proporcjonalności. De Saussure, który tak odkrywczo uchwycił istotę mechanizmu mownego, sprowadzając go do układów algebraicznych, mylił się jednak, twierdząc, że do zaistnienia języka wystarczą jedynie dwie formy (na przykład $b a$ i la), zdolne do uporządkowania wszystkich koniecznych w nim znaczeń po stronie jednej bądź drugiej z nich ${ }^{32}$. Odpowiednich form i związanych $\mathrm{z}$ nimi znaczeń musi być co najmniej cztery, bo dopiero w takich warunkach można mówić o czwórce proporcjonalnej ${ }^{33}$.

${ }^{31} \mathrm{Na}$ temat adekwatnej delimitacji ciągu wypowiedzeniowego zob. np. F. de Saussure, Kurs..., op. cit., s. 125-129; A. Bogusławski, O zasadach rejestracji jednostek języka, „Poradnik Językowy” 1976, nr 8, s. 356-364; idem, Jednostki języka a produkty językowe. Problem tzw. orzeczeń peryfrastycznych, [w:] Z zagadnień słownictwa współczesnego języka polskiego, red. M. Szymczak, Wrocław 1978, s. 17-30; idem, Jeszcze o delimitacji bilateralnych wielkości językowych, [w:] Symbolae Slavisticae. Dedykowane Pani Profesor Hannie Popowskiej-Taborskiej, red. E. Rzetelska-Feleszko, Warszawa 1996, s. 47-56.

32 F. de Saussure, Szkice..., op. cit. s. 95.

33 Na ten temat zob. więcej w artykule: A. Bogusławski, An Example of Non-Existence of What Fails to Meet the Proportionality Requirement, [w:] Language, Science and Culture: Essays in Honour of Professor Jerzy Bańczerowski on the Occasion of His 70th Birthday, red. P. Łobacz, P. Nowak, W. Zabrocki, Poznań 2009, s. 85-90. 


\section{ŚRODKI W JEZZYKU NIEZBĘDNE}

W ostatniej części tego artykułu chcę powiedzieć kilka słów o wyposażeniu języka w wyrażenia, które są niezbędne do zbudowania jakiejkolwiek wypowiedzi, oraz w inne konieczne do tego celu środki wyrazu.

\section{WYRAŻENIA PREDYKATYWNE I REFERENCJALNE}

Na mówienie - jak przenikliwie pokazał to John L. Austin, reprezentant brytyjskiego nurtu filozofii analitycznej - składa się bardzo wiele różnych czynności. Dwie z nich są jednak absolutnie podstawowe, a chodzi mianowicie, po pierwsze, o akt referencji, czyli odesłania tego, co się mówi, do odpowiednich przedmiotów w świecie, i po drugie - o akt predykacji (lub orzekania), czyli przypisania danemu przedmiotowi odpowiedniej wiązki $\operatorname{cech}^{34}$. Mówienie to, innymi słowy, wskazywanie obiektów w świecie i charakteryzowanie ich pod pewnym względem. I tak na przykład w zdaniu: Janek pracuje wskazujemy wiadomą osobę, której na imię Janek, i orzekamy o niej, że w momencie mówienia pracuje. Do każdorazowego spełnienia tych dwóch czynności konieczne są wyspecjalizowane środki językowe. Z jednej strony, mówiący musi dysponować wyrażeniami referencjalnymi lub indeksalnymi, takimi jak imiona własne, różnego rodzaju zaimki czy rodzajniki, które pozwalają mówić nie tylko o tym, co pozostaje w zasięgu palca wskazującego, z drugiej zaś - niezależnymi od tamtych wyrażeniami predykatywnymi, należącymi do rozmaitych części mowy. Z łatwością można sobie wyobrazić język, w którym nie byłoby pewnej klasy predykatów, na przykład tego, co nazywamy rzeczownikami, albo tego, czemu przypisujemy nazwę czasownika, a tym bardziej tego, co określamy mianem spójnika, ale rozróżnienie między indeksami a orzecznikami musi być zachowane pod groźbą zachwiania istotą zdarzenia mownego. I nic nie szkodzi, że nie ma w języku czystych indeksów - takich, które byłyby całkiem wolne od treści predykatywnych, bo nawet imiona własne nie są pozbawione elementarnego znaczenia; ważna jest dominacja jednej z tych funkcji, tworząca wyrazistą opozycję.

34 Por. J.L. Austin, Jak działać słowami, [w:] idem: Mówienie i poznawanie. Rozprawy i wykłady filozoficzne, tłum. B. Chwedeńczuk, Warszawa 1993, s. 640-644. 


\section{WYRAŻENIA Z POZIOMU PRZEDMIOTOWEGO I METAPRZEDMIOTOWEGO}

W każdym języku, obok wyrażeń służących do reprezentowania zjawisk należących do rzeczywistości pozajęzykowej, muszą też istnieć środki służące do mówienia o mówieniu, to znaczy odsyłające do innych wyrażeń tego samego systemu językowego ${ }^{35}$. Jest to znowu jedna $\mathrm{z}$ tych cech, których próżno by szukać w kodach zwierzęcych. Wyżej zorganizowane małpy zdolne są z pewnością do tego, by sygnalizować opiekunowi chęć uzyskania pożywienia, ale nie mogą wysyłać komunikatów na temat tych właśnie sygnałów. Jest to związane $\mathrm{z}$ faktem, który w swej teorii lingwistycznej akcentuje A. Bogusławski, a mianowicie że zwierzęta, podobnie jak ludzie, wiedzą różne rzeczy o świecie, ale nie mogą nic wiedzieć o własnej wiedzy, brak im bowiem autorefleksji.

W języku naturalnym możliwy jest nie tylko namysł nad systemem jako całością (taki charakter ma mój artykuł), nad tym czy innym elementem kodu (np. Słowo „kot” jest jednosylabowe) lub nad zrealizowanymi w nim wypowiedziami (np. „Słowo »kot « jest jednosylabowe” - to dobry przykład metawypowiedzi). Wskazane wyżej operacje dokonywane są w parole za pomocą niespecyficznych narzędzi, ale i w samym języku (langue) znajdujemy elementy wyspecjalizowane do pełnienia funkcji metatekstowych. W repertuarze jego środków ważne miejsce zajmują bowiem takie, które pod względem semantycznym są ściągniętymi do postaci jednostki leksykalnej komentarzami na temat spełnianych aktualnie czynności mownych. W polszczyźnie taką rolę mają do odegrania partykuły typu: raczej, chyba, może, bynajmniej nie ${ }^{36}$, czy też bardziej przejrzysty metatekst w rodzaju: krótko mówiąc, innymi słowy, by tak rzec i wyrażenia tym podobne.

Impuls do rozpoczęcia badań nad metajęzykiem na gruncie lingwistyki dały osiągnięcia wybitnych filozofów XX wieku, a w szczególności Alfreda Tarskiego, który wypracowując swą teorię prawdy, założył, że znajomość

35 Ta własność języka została dostrzeżona już w starożytnych Indiach, około 500 lat p.n.e. Na temat historii rozważań o metajęzyku zob. A. Bogusławski, E. Drzazgowska, op. cit., t. II, s. 486-522.

36 Trzy ostatnie partykuły w przywołanym szeregu to na przykład króciutkie opowieści o tym, że wiedza mówiącego jest niedostateczna, by pod asercją głosić to, co po nich następuje. 
danego języka naturalnego implikuje znajomość jego metajęzyka, a ta z kolei znajomość metametajęzyka itd., to znaczy zdolność odnoszenia się do wyrażeń jako do tego, o czym mowa, oraz przekładania wyrażeń z poziomu przedmiotowego na wyrażenia metapoziomu z zachowaniem ich znaczenia ${ }^{37}$.

\section{3. ŚRODKI SŁUŻĄCE DO PRZEKAZYWANIA WIEDZY I KOMUNIKOWANIA PRAWDY}

Podstawową funkcją języka jest funkcja określana mianem symbolicznej, reprezentatywnej bądź referencjalnej. Jednostki znaczące mają bowiem zdolność reprezentowania odpowiednich obiektów w rzeczywistości pozajęzykowej i językowej, a także wszelkich relacji między tymi obiektami. Poszczególne realizacje systemu w postaci konkretnych wypowiedzi pełnią natomiast przede wszystkim funkcję poznawczą. Głównym sensem użycia języka w indywidualnym akcie mowy jest bowiem przekazanie odbiorcy pewnej porcji wiedzy. Komunikacja językowa to w pierwszym rzędzie dzielenie się ze współrozmówcami wiedzą. Takie efekty, jak manifestowanie swoich stanów emocjonalnych, wywieranie presji na odbiorcę, osiąganie celów fatycznych czy poetyckich - wszystko to są rzeczy wtórne i nadbudowane nad aspektami poznawczymi.

Badania nad rekonstrukcją systemu pojęć prostych i uniwersalnych, prowadzone w różnych ośrodkach naukowych na materiale języków różniących się w sposób zasadniczy strukturą, dostarczają przekonujących argumentów na rzecz tezy, że jednym $z$ bazowych indefinibiliów jest pojęcie związane z polskim czasownikiem wiedzieć, $\dot{z} e_{-}, \mathrm{z}$ francuskim savoir que_, $\mathrm{z}$ angielskim know that_, z rosyjskim znat' čto_itd. Bogusławski, który problematyce kognitywnej w języku naturalnym poświęcił swoje najważniejsze prace ${ }^{38}$, zwraca uwagę nie tylko na eksplanacyjną moc pojęcia wiedzy (będącą refleksem tego, że jest ono składnikiem ogromnej większości pojęć złożonych występujących w poszczególnych językach), lecz także na fakt,

37 Zob. np. A. Tarski, Pisma logiczno-filozoficzne, t. 1: Prawda, Warszawa 1995, s. 292-332.

38 Mam tu przede wszystkim na myśli dwie obszerne monografie tego autora, a mianowicie: Science as Linguistic Activity, Linguistics as Scientific Activity (Warszawa 1998) i A Study in the Linguistics-Philosophy Interface (Warszawa 2007). 
że każde sensownie użyte zdanie oznajmujące ma implikację epistemiczną. Znaczy to tyle, że z użytego zdania $p$ logicznie wynika, iż ktoś wie, że p.

Co więcej, w każdym zdaniu oznajmującym wypowiedzianym pod asercją, to znaczy na serio, z przeżyciem pewności, w takim, które można zreferować za pomocą akcentowanej frazy ktoś powiedziat, $\dot{z} e_{-}$, zawarte jest tak zwane truth-claim, czyli swoiste nastawanie nadawcy na prawdziwość spełnianego przezeń wypowiedzenia. Ten bardzo ważny element nie ma swoich wykładników segmentalnych, zasadniczą rolę odgrywają tu środki prozodyczne, związane przede wszystkim z intonacją kadencji. Implikacja epistemiczna i truth-claim sprawiają, że mówienie, które nie dotykałoby wiedzy i prawdy - to rzecz po prostu niemożliwa.

W artykule pod znaczącym tytułem Veredicum laudare necesse est, vitam sustinere non est necesse ${ }^{39}$ Bogusławski zwraca uwagę na to, że prawda zajmuje w języku szczególne miejsce. Jest ona logicznie wyróżniona w stosunku do dobra (a więc też takich cnót, jak życzliwość, miłosierdzie, wielkoduszność), a także w stosunku do piękna. Swoją tezę opiera on na obserwacji, popartej wywodem logicznym, że całkowita i ostateczna aprobata dla świadomie głoszonej nieprawdy jest wewnętrznie sprzeczna, podczas gdy taka sama aprobata dla prawdy nigdy sprzeczna nie jest. Ktokolwiek bowiem aprobuje mówienie przez inną osobę rzeczy, które są całkowicie nieprawdziwe, nie może jednocześnie nie odnosić się z aprobatą do tego, co z jego punktu widzenia jest prawdziwe, a mianowicie do własnej pozytywnej oceny owych fałszów. Inne wartości i antywartości takiej asymetrii nie wykazują.

Lingwistyczny prymat prawdy przed dobrem i pięknem potwierdzają dane płynące $\mathrm{z}$ różnych języków. Przekonujące przykłady Bogusławskiego dają świadectwo temu, że prawda wykazuje uderzającą niezależność od innych wartości. Zdanie: Byłoby to piękne/dobre, gdyby było prawdziwe jest nie tylko całkowicie akceptowalne, ale - co więcej - często używane, podczas gdy wypowiedzenie: ${ }^{\star} B y ł o b y$ to prawdziwe, gdyby było piękne/dobre musi być uznane za nieakceptowalne.

Świadome pogwałcenie przez mówiącego prawdziwości wypowiedzi skutkuje wytworzeniem się niewłaściwego i szkodliwego obrazu odpowiedniego

39 A. Bogusławski, Veredicum laudare necesse est, vitam sustinere non est necesse, "Journal of Pragmatics” 2005, No. 37, s. 411-431; przedruk w: idem, Roztrząsania nadlingwistyczne, Warszawa 2011, s. 51-74. 
fragmentu rzeczywistości w umyśle odbiorcy, co z kolei grozi gotowością tegoż do działania w nieadekwatny sposób; konsekwencje fałszu są więc zarówno z praktycznego, jak i aksjologicznego punktu widzenia daleko idące. Całkowite zerwanie z prawdziwością w komunikacji ludzkiej, a w efekcie załamanie się wzajemnego zaufania, prowadziłoby do podkopania fundamentów języka, a ostatecznie - do anihilacji życia społecznego. Z pewnością dlatego właśnie nie istnieje taki system etyczny, w którym wybór między mówieniem prawdy i nieprawdy byłby rzeczą obojętną.

\section{PODSUMOWANIE}

W tej krótkiej wypowiedzi mogłam zasygnalizować jedynie wybrane problemy związane ze sprawą konieczności w języku naturalnym. Podsumowując swoje rozważania, raz jeszcze chcę podkreślić, że jest on taką instytucją, której nie da się zestawić z żadnym innym systemem komunikacyjnym czy to w porządku natury, czy też w dziedzinie kultury. Banalne i - wydawałoby się - czysto strukturalne własności języka wyprowadzają nas od razu nieuchronnie w sferę podstawowych zagadnień ontologicznych, epistemologicznych i aksjologicznych.

\section{Bibliografia:}

John L. Austin, Jak działać słowami, [w:] idem, Mówienie i poznawanie. Rozprawy i wykłady filozoficzne, tłum. B. Chwedeńczuk, PWN, Warszawa 1993.

Jean Aitchison, Ziarna mowy. Początki i rozwój języka, tłum. M. Sykurska-Derwojed, PWN, Warszawa 2002.

Ireneusz Bobrowski, Zaproszenie do językoznawstwa, Wyd. Instytutu Języka Polskiego PAN, Kraków 1998.

Andrzej Bogusławski, O zasadach rejestracji jednostek języka, „Poradnik Językowy” 1976, nr 8, s. 356-364.

Andrzej Bogusławski, Jednostki języka a produkty językowe. Problem tzw. orzeczeń peryfrastycznych, [w:] Z zagadnień słownictwa współczesnego języka polskiego, red. M. Szymczak, Ossolineum, Wrocław 1978, s. 17-30.

Andrzej Bogusławski, Towards an operational grammar, "Studia Semiotyczne” 1978, nr 8, 29-90, pol. przekład: Preliminaria gramatyki operacyjnej, tłum. R. Gozdawa-Gołębiowski, „Polonica” 1989, nr 13, s. 163-223. 
Andrzej Bogusławski, Język i świat znaków, „Przegląd Humanistyczny” 1988, nr 12, s. 133-168; przedruk w: idem, Sprawy słowa / Word Matters, Veda, Warszawa 1944, s. 22-48.

Andrzej Bogusławski, O proporcjonalności w języku i jej warunkach, [w:] Językoznawstwo diachroniczne i synchroniczne, red. J. Sambor, J. Linde-Usiekniewicz, R. Huszcza, Wydawnictwo UW, Warszawa 1993, s. 59-76.

Andrzej Bogusławski, Jeszcze o delimitacji bilateralnych wielkości językowych, [w:] Symbolae Slavisticae. Dedykowane Pani Profesor Hannie Popowskiej-Taborskiej, red. E. Rzetelska-Feleszko, Slawistyczny Ośrodek Wydawniczy, Warszawa 1996, s. 47-56.

Andrzej Bogusławski, Science as Linguistic Activity, Linguistics as Scientific Activity, Katedra Lingwistyki Formalnej UW, Warszawa 1998.

Andrzej Bogusławski, Veredicum laudare necesse est, vitam sustinere non est necesse, „Journal of Pragmatics” 2005, nr 37, s. 411-431; przedruk w: idem, Roztrzasania nadlingwistyczne, Bel STUDIO, Warszawa 2011, s. 51-74.

Andrzej Bogusławski, A Study in the Linguistics-Philosophy Interface, Katedra Lingwistyki Formalnej UW, Warszawa 2007.

Andrzej Bogusławski, An Example of Non-Existence of What Fails to Meet the Proportionality Requirement, [w:] Language, Science and Culture: Essays in Honour of Professor Jerzy Bańczerowski on the Occasion of His 70th Birthday, red. P. Łobacz, P. Nowak, W. Zabrocki, Wydawnictwo Naukowe UAM, Poznań 2009, s. 85-90.

Andrzej Bogusławski, Słowo i znak, [w:] Znaki czy nie znaki?, red. M. Guławska-Gniewkowska, G.M. Zeldowicz, Instytut Lingwistyki Stosowanej, Warszawa, 2013, s. 9-19.

Andrzej Bogusławski, Ewa Drzazgowska, Język w refleksji teoretycznej. Przekroje historyczne, t. I-II, Katedra Lingwistyki Formalnej UW, Warszawa 2016.

Bożenna Bojar, Zarys językoznawstwa dla studentów bibliotekoznawstwa i informacji naukowej, Wydawnictwo UW, Warszawa 1991.

Georges Charbonnier, Rozmowy z Claude Lévi-Straussem, tłum. J. Trznadel, Czytelnik, Warszawa 2000.

William H. Calvin, Derek Bickerton, Lingua ex Machina. Reconciling Darwin and Chomsky with the Human Brain, MIT Press, Cambridge 2001.

Magdalena Danielewiczowa, Dosięgnąć przedmiotu. Rzecz o Ferdynandzie de Saussurze, Wydawnictwo UW, Warszawa 2016. 
Cliff Goddard, Anna Wierzbicka, Horacio Fabréga Jr., Evolutionary Semantics:

Using NSM to Model Stages in Human Cognitive Evolution, „Language Sciences" 2013, No. 42, s. 60-79.

Renata Grzegorczykowa, Wstęp do językoznawstwa, PWN, Warszawa 2007.

Charles F. Hockett, Zagadnienie uniwersaliów w języku, tłum. H. Kurkowska,

[w:] Językoznawstwo strukturalne, red. A. Weinsberg, H. Kurkowska, PWN, Warszawa 1979, s. 209-228.

Roman Jakobson, Język a inne systemy komunikacji, przeł. A. Tanalska, [w:] idem

W poszukiwaniu istoty języka. Wybór pism, red. M.R. Mayenowa, t. I, PWN, Warszawa 1989, s. 59-74.

Jerzy Kuryłowicz, La nature des pročcs dits «analogiques», SPAU, Kraków 1949.

Richard Leakey, Pochodzenie człowieka, tłum. Z. Skrok, CIS, MOST, Warszawa 1995.

John Lyons, Language and Linguistics. An Introduction, CUP, Cambridge 1981. Edward Łuczyński, Jolanta Maćkowiak, Językoznawstwo ogólne. Wybrane zagadnienia, Wydawnictwo UG, Gdańsk 1999.

André Martinet, Éléments de linguistique générale, Armand Colin, Paris 1960; pol. wydanie: Podstawy lingwistyki funkcjonalnej, wybór i tłum. L. Zawadowski, PWN, Warszawa 1970, s. 18-24; lub przedruk: [Podwójne rozczłonkowanie języka], [w:] Semiotyka dziś i wczoraj, red. L. Koj, J. Pelc, Ossolineum, Wrocław 1991, s. 342-345.

Ferdynand de Saussure, Kurs językoznawstwa ogólnego, tłum. K. Kasprzyk, PWN, Warszawa 2002.

Ferdinand de Saussure, Szkice zjęzykoznawstwa ogólnego, przeł. M. Danielewiczowa, Dialog, Warszawa 2004.

Steven Pinker, Język jest instynktem ludzkim, tłum. J. i M. Jannaszowie, [w:] Trzecia kultura, red. J. Brockman, CIS, Warszawa 1996.

Renata Przybylska, Wstęp do nauki o języku polskim. Podręcznik dla szkół wyższych, Wydawnictwo Literackie, Kraków 2003.

Max Scheler, Pisma $z$ antropologii filozoficznej i teorii wiedzy, tłum. i oprac.

S. Czerniak, Węgrzecki, PWN, Warszawa 1987.

Alfred Tarski, Pisma logiczno-filozoficzne, t. 1: Prawda, Wydawnictwo Naukowe PWN, Warszawa 1995.

Ludwig Wittgenstein, Philosophische Grammatik, hrsg. von R. Rhees, Suhrkamp, Frankfurt am Main 1989. 
Ludwig Wittgenstein, Tractatus logico-philosophicus, tłum. B. Wolniewicz, PWN, Warszawa 2006.

Przemysław Żywiczyński, Sławomir Wacewicz, Ewolucja języka. W stronę hipotez gesturalnych, Wydawnictwo UMK, Lublin 2015.

\section{What is Language Necessary for? What is Necessary in the Language Itself?}

The article attempts to answer two closely interrelated questions: What is a natural language necessary for and, on the other hand, what is necessary in the language itself? In the first part the author puts forward a thesis that there is a gulf between human speech and animal codes - a gulf which cannot be filled with explanations of evolutionary nature. She also invokes a series of ideas of distinguished scholars who advocate the logical primacy of language in relation to all other semiotic systems that create the space of culture. In the second part of the article, the inalienable properties of language are discussed, those that determine its essence and, at the same time, the uniqueness with respect to both the animal signals and all other sign systems. These features include: double demarcation, duality, proportionality, the possession of reference and predictive expressions, metalinguistic and metatextual tools, as well as tools for communicating the truth and knowledge of the world.

Keywords: linguistics, semiotics, natural language, animal codes, inalienable features of human language 